\title{
Application of the functionalized congener approach to dendrimer-based signaling agents acting through $\mathrm{A}_{2 \mathrm{~A}}$ adenosine receptors
}

\author{
Yoonkyung Kim • Athena M. Klutz • Béatrice Hechler • \\ Zhan-Guo Gao • Christian Gachet • \\ Kenneth A. Jacobson
}

Received: 28 January 2008 / Accepted: 30 April 2008 / Published online: 4 July 2008

(C) Springer Science + Business Media B.V. 2008

\begin{abstract}
As a continued effort to develop multivalent ligands to enhance the pharmacological effects of monomeric drugs, DITC-APEC, a chemically reactive nucleoside $\mathrm{A}_{2 \mathrm{~A}}$ adenosine receptor (AR) agonist, was employed to derivatize the surface of third-generation (G3) polyamidoamine (PAMAM) dendrimers. The resulting conjugates carried multiple copies of the agonist attached through a thiourea linkage and differed in the number of attachments and in the presence of a fluorophore or additional surface
\end{abstract}

Electronic supplementary material The online version of this article (doi:10.1007/s11302-008-9113-3) contains supplementary material, which is available to authorized users.

Y. Kim·A. M. Klutz 'Z.-G. Gao • K. A. Jacobson $(\bowtie)$

Molecular Recognition Section, Laboratory of Bioorganic

Chemistry, National Institute of Diabetes and Digestive \& Kidney

Diseases, National Institutes of Health,

Bethesda, MD 20892, USA

e-mail: kajacobs@helix.nih.gov

B. Hechler · C. Gachet

INSERM U.311,

Strasbourg, France

B. Hechler · C. Gachet

EFS-Alsace,

Strasbourg, France

B. Hechler · C. Gachet

Université Louis Pasteur,

Strasbourg, France

Present address:

Y. Kim

Biomedical Research Center,

Korea Institute of Science and Technology,

39-1 Hawolgok-dong, Seongbuk-gu,

Seoul 136-791, Korea modification. Computer modeling studies suggested that these DITC-APEC-loaded dendrimers extended the overall diameter of the previously reported PAMAM-CGS21680 dendrimer derivatives (Kim et al., Bioconjugate Chem 2008 $19: 406-411)$ by ca. $20 \AA$, potentially increasing the conformational flexibility of the appended ligands to achieve optimal geometry for efficient binding at $\mathrm{A}_{2 \mathrm{~A}}$ ARs. Increased affinity and selectivity in binding in comparison to the CGS21680 conjugate were envisioned, due to the presence of an extended linker, i.e., a dithioureylenephenyl functionality. In vitro radioligand competition experiments showed effective binding of these PAMAM-DITC-APEC dendrimer conjugates at the human $\mathrm{A}_{2 \mathrm{~A}}$ and $\mathrm{A}_{3}$ ARs with submicromolar $K_{\mathrm{i}}$ values and selectivity in comparison to the human $\mathrm{A}_{1}$ AR. Furthermore, these nucleoside-loaded dendrimers exhibited an $\mathrm{A}_{2 \mathrm{~A}}$ AR-mediated inhibitory effect on ADPinduced aggregation of human platelets. The present study demonstrates the potential of applying the functionalized congener concept to engineer dendrimer-based multivalent ligands for $\mathrm{G}$ protein-coupled receptors.

Keywords $\mathrm{A}_{2 \mathrm{~A}}$ adenosine receptors - Dendrimers . Functionalized congeners $\cdot G$ protein-coupled receptors . Antithrombotic · Nanotechnology

$\begin{array}{ll}\begin{array}{l}\text { Abbreviations } \\ \text { ADP }\end{array} & \begin{array}{l}\text { Adenosine 5'-diphosphate } \\ \text { APEC }\end{array} \\ & \begin{array}{l}\text { 2-[4-(2-Aminoethylaminocarbonylethyl) } \\ \text { phenylethylamino]-5'- } N \text {-ethylcarboxamidoa- } \\ \text { denosine }\end{array} \\ & \text { Adenosine receptor } \\ \text { AR } & \text { Tert-butoxycarbonyl } \\ \text { Boc } & \text { Chinese hamster ovary } \\ \text { CHO } & \text { Correlation spectroscopy }\end{array}$




$\begin{array}{ll}\text { CGS21680 } & \text { 2-[4-(2-Carboxylethyl)phenylethylamino]- } \\ & 5 \text { '- } N \text {-ethylcarboxamidoadenosine } \\ \text { DIEA } & N, N \text {-diisopropylethylamine } \\ \text { DITC-APEC } & \text { 4-Isothiocyanatophenylaminothiocarbonyl- } \\ & \text { APEC } \\ \text { DMF } & N, N \text {-dimethylformamide } \\ \text { DMSO } & \text { Dimethyl sulfoxide } \\ \text { ED } & \text { Ethylenediamine } \\ \text { GPCR } & \text { G protein-coupled receptor } \\ \text { HEK } & \text { Human embryonic kidney } \\ \text { NMR } & \text { Nuclear magnetic resonance } \\ \text { NOESY } & \begin{array}{l}\text { Nuclear Overhauser enhancement } \\ \text { spectroscopy }\end{array} \\ \text { PAMAM } & \begin{array}{l}\text { Polyamidoamine } \\ \text { PyBOP }\end{array} \\ & \begin{array}{l}\text { Benzotriazol-1-yl-oxytripyrrolidinophospho- } \\ \text { nium hexafluorophosphate }\end{array} \\ \text { SCH442416 } & \text { 5-Amino-7-(3-(4-methoxy)phenylpropyl)-2- } \\ & \text { (2-furyl)pyrazolo[4,3-e]-1,2,4-triazolo[1, } \\ & \text { 5-c]pyrimidine } \\ \text { SEC } & \text { Size exclusion chromatography }\end{array}$

\section{Introduction}

Ligand interactions with cell-surface receptors, such as GPCRs, are employed to modulate cellular functions for the treatment of diseases. An example of this strategy is to develop high-affinity synthetic ligands with enhanced potency and receptor selectivity. In addition to the classical medicinal chemical approach of structural modification of small monomeric drugs, one way to achieve higher binding affinity and selectivity of a given ligand for its receptor is to anchor multiple copies of the ligand to a single macromolecular carrier such as a dendrimer [1-4].

Dendrimers have a treelike macromolecular architecture which are prepared through iterative organic synthesis and can serve as nanocarriers for drug delivery [5-7]. Due to its well-defined chemical structure, the dendrimer carrier may display more consistent biological effects than conventional polymeric drug delivery systems, such as vinyl polymers, polysaccharides, synthetic poly $(\alpha$-amino acids), and poly (ethylene glycol). Furthermore, its globular shape may improve the pharmacokinetic properties of a bound drug [1]. The anticipated cooperative effect from simultaneous multivalent ligand-receptor binding mediated by a single dendritic scaffold may impart additional affinity and selectivity in a manner not possible using small molecules [8]. Given the appropriate geometry, a multivalent effect could take advantage of complex assemblies of GPCRs or clustering that may be present on the cell surface [9].

The functionalized congener approach, originally introduced for GPCR drug design, involves structural variation at the distal unit of a pre-existing ligand in order to improve its pharmacological effects $[10,11]$. The key pharmacophore unit of a small molecular ligand for a GPCR generally binds within its heptahelical transmembrane domain $[12,13]$. In the case of functionalized congeners, the distal chemical functionality of an appended chain may reside and potentially interact at/near the extracellular domain of the GPCR. Indeed, improving this secondary interaction can significantly enhance the affinity and selectivity of certain ligands. Such modulation of the pharmacological profile can be achieved at the distal unit through a variation of the linker length, functional group manipulation, or a combination of both techniques.

The $\mathrm{A}_{2 \mathrm{~A}}$ adenosine receptor (AR) is one of the four known AR subtypes relevant to various diseases including thrombosis, inflammation, nervous system disorders, and ischemia reperfusion damage [14-16]. Recently, we have reported using a dendritic scaffold to load multiple copies of the $\mathrm{A}_{2 \mathrm{~A}} \mathrm{AR}$ agonist, CGS21680 4, to create a macromolecular drug carrier system [17]. Here, in an effort to expand the development of dendrimer-based multivalent ligands for GPCRs, we have incorporated DITC-APEC 2 [18-20] to the surface of a third-generation (G3) PAMAM dendrimer 6 [21] by forming a thiourea linkage. Previously, DITC-APEC, an $A_{2 A}$ AR-specific agonist, was shown to irreversibly activate the AR signaling pathway through covalent attachment at the extracellular domain of the receptor $[18,19]$. The present study demonstrates the application of the functionalized congener approach to polyvalent ligand design.

\section{Materials and methods}

Glassware was oven-dried and cooled in a desiccator before use. All reactions were carried out under a dry nitrogen atmosphere. Solvents were purchased as anhydrous grade and used without further purification. Suppliers of the commercial compounds are as follows: amine-terminated G3 PAMAM dendrimer with an ethylenediamine core, acetic anhydride $\left(\mathrm{Ac}_{2} \mathrm{O}\right), \mathrm{N}$-(2-aminoethyl)acetamide, triethylamine, $N, N$-diisopropylethylamine (DIEA), dimethyl sulfoxide (DMSO), acetonitrile $\left(\mathrm{CH}_{3} \mathrm{CN}\right)$, methanol $(\mathrm{MeOH})$, chloroform $\left(\mathrm{CHCl}_{3}\right)$, and isopropanol were purchased from Aldrich; $N, N$-dimethylformamide (DMF) was purchased from Acros; DMSO- $d_{6}$ was purchased from Cambridge Isotope Laboratories; 5-carboxyfluorescein succinimidyl ester was purchased from Invitrogen; 2-[4-(2aminoethylaminocarbonylethyl)phenylethylamino] $-5^{\prime}-\mathrm{N}$ ethylcarboxamidoadenosine (APEC) bistrifluoroacetic acid was provided by NIMH Chemical Synthesis and Drug Supply Program. Radioligands were purchased from Perkin Elmer Life and Analytical Science.

Thin-layer chromatography (TLC) was performed on $0.2 \mathrm{~mm}$ silica glass coated sheets (E. Merck) with F-254 
indicator. Visualization of the products on TLC plates was performed by UV light, potassium permanganate, or iodine. Preparative SEC was performed on Bio-Beads ${ }^{\circledR}$ S-X1 beads (BIO-RAD, MW operating range from 600-14,000 Da), 200400 mesh, with DMF (Aldrich 99.8\%, anhydrous) as an eluent at ambient pressure.

NMR spectra were recorded on a Bruker DRX-600 spectrometer at $25.0^{\circ} \mathrm{C}$ under an optimized parameter setting for each sample, unless otherwise mentioned. ${ }^{1} \mathrm{H}$ NMR chemical shifts were measured relative to the residual solvent peak at $2.50 \mathrm{ppm}$ in DMSO- $d_{6}$. Complete NMR peak assignments were made possible with 2D COSY and NOESY experiments. For dendrimer conjugates, only the peaks clearly resolved in the ${ }^{1} \mathrm{H}$ NMR spectra were listed. Since the MW of each dendrimer conjugate was determined as the average value from its polymeric distribution and the dendrimer structure was not unimolecular, the integration value of each peak was reported to two decimal places as determined by the ${ }^{1} \mathrm{H}$ NMR analysis. A methylene peak of PAMAM dendrimer near 2.20 ppm ("c", see peak labeling of 10) was used as an internal standard (set at $120 \mathrm{H}$ ) for the integration, assuming 32 peripheral groups without any defects in the structure. Full peak assignments of dendrimer conjugates are shown in the Supporting Information.

The electrospray ionization (ESI) MS experiments were performed on a Waters LCT Premier mass spectrometer at the Mass Spectrometry Facility, NIDDK, NIH.

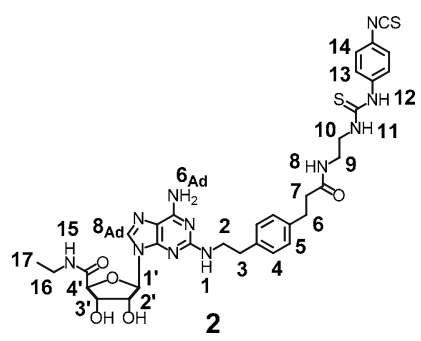

$D I T C-A P E C 2$ The synthesis of this compound was reported previously [20] APEC $1(54.0 \mathrm{mg}, 70.2 \mu \mathrm{mol}$, as a 2 TFA salt) and diisothiocyanatobenzene $(40.0 \mathrm{mg}$, $208 \mu \mathrm{mol})$ were dissolved in a mixture of $1: 1 \mathrm{CH}_{3} \mathrm{CN} /$ isopropanol $(5 \mathrm{~mL})$, and then triethylamine $(100 \mu \mathrm{L}$, $718 \mu \mathrm{mol})$ was added to this mixture. The reaction was stirred for $2 \mathrm{~h}$ at room temperature, the solvent was removed in vacuo, and the crude product was purified by preparative TLC $\left(4: 1 \mathrm{CHCl}_{3} / \mathrm{MeOH}\right)$ to give $41.4 \mathrm{mg}$ $(56.4 \mu \mathrm{mol}, 80 \%)$ of $\mathbf{2}$ as a white solid. Prolonged reaction time increased the amounts of side-products. $R_{\mathrm{f}}: 0.40$ [silica gel, 4:1 $\mathrm{CHCl}_{3} / \mathrm{MeOH}$ ]; ${ }^{1} \mathrm{H}$ NMR (600 MHz, DMSO- $\left.d_{6}\right) \delta$ 9.80 (br s, $1 \mathrm{H}, \mathrm{H}_{12}$ ), 8.04 (br s, $\left.1 \mathrm{H}, \mathrm{H}_{15}\right), 8.02(\mathrm{~s}, 1 \mathrm{H}$, $\left.\mathrm{H}_{8 \mathrm{Ad}}\right), 8.00\left(\mathrm{~s}, 1 \mathrm{H}, \mathrm{H}_{8}\right), 7.92\left(\mathrm{~s}, 1 \mathrm{H}, \mathrm{H}_{11}\right), 7.53$ (d, 2H, J= $\left.7.5 \mathrm{~Hz}, \mathrm{H}_{14}\right), 7.37$ (d, 2H, J=7.4 Hz, H13), 7.15 (d, 2H, J= $8.3 \mathrm{~Hz}, \mathrm{H}_{4} / \mathrm{H}_{5}$ ), 7.11 (d, $2 \mathrm{H}, \mathrm{J}=7.8 \mathrm{~Hz}, \mathrm{H}_{4} / \mathrm{H}_{5}$ ), 6.79 (br s, $\left.2 \mathrm{H}, \mathrm{H}_{6 \mathrm{Ad}}\right), 6.20\left(\mathrm{t}, 1 \mathrm{H}, \mathrm{J}=5.2 \mathrm{~Hz}, \mathrm{H}_{1}\right), 5.84(\mathrm{~d}, 1 \mathrm{H}, \mathrm{J}=$ $7.6 \mathrm{~Hz}, \mathrm{H}_{1^{\prime}}$ ), 5.58 (d, 1H, J=4.6 Hz, $\left.\mathrm{H}_{3^{\prime}-\mathrm{OH}}\right), 5.50$ (d, 1H, J= $6.2 \mathrm{~Hz}, \mathrm{H}_{2^{\prime}-\mathrm{OH}}$ ), 4.72 (dd, $1 \mathrm{H}, \mathrm{J}=11.0,6.0 \mathrm{~Hz}, \mathrm{H}_{2^{\prime}}$ ), 4.25 (d, $\left.1 \mathrm{H}, \mathrm{J}=2.4 \mathrm{~Hz}, \mathrm{H}_{4^{\prime}}\right), 4.18\left(\mathrm{~m}, 1 \mathrm{H}, \mathrm{H}_{3^{\prime}}\right), 3.52\left(\mathrm{~m}, 2 \mathrm{H}, \mathrm{H}_{10}\right)$, 3.49-3.34 (m, 2H, H2), 3.25 (q, 2H, J=6.1 Hz, H9), 3.20$3.03\left(\mathrm{~m}, 2 \mathrm{H}, \mathrm{H}_{16}\right), 2.77\left(\mathrm{~m}, 4 \mathrm{H}, \mathrm{H}_{3}\right.$ and $\left.\mathrm{H}_{6}\right), 2.36(\mathrm{t}, 2 \mathrm{H}, \mathrm{J}=$ $\left.7.8 \mathrm{~Hz}, \mathrm{H}_{7}\right), 0.97$ (t, 3H, J=7.1 Hz, H $\mathrm{H}_{17}$ ); HRMS (ESI) calculated for $\mathrm{C}_{33} \mathrm{H}_{40} \mathrm{~N}_{11} \mathrm{O}_{5} \mathrm{~S}_{2}\left(\mathrm{M}+\mathrm{H}^{+}\right)$: 734.2655, found: 734.2674 .

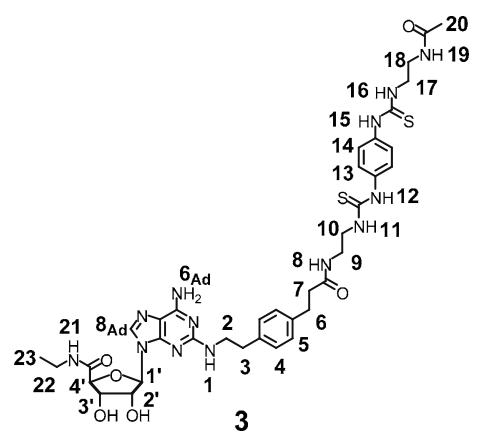

APEC monomeric control 3 DITC-APEC 2 (5.26 mg, $7.17 \mu \mathrm{mol})$ was dissolved in $\mathrm{DMSO}-d_{6}(300 \mu \mathrm{L})$, and triethylamine $(20 \mu \mathrm{L}, 144 \mu \mathrm{mol})$ was added to this solution. $N$-Acetylethylenediamine $(2.00 \mu \mathrm{L}, 18.8 \mu \mathrm{L}, 90 \%$ tech.) was added to this stirred mixture. The reaction was stirred for $16 \mathrm{~h}$ at room temperature. The solvent was removed in vacuo, and the crude product was purified by preparative TLC $\left(5: 2 \mathrm{CHCl}_{3} / \mathrm{MeOH}\right)$ to give $0.89 \mathrm{mg}(1.56 \mu \mathrm{mol}$, $22 \%$ ) of $\mathbf{3}$ as a white solid. Low yield of this reaction could be due to the highly polar nature of the desired compound 3, which was difficult to completely recover from the silica gel. $R_{\mathrm{f}}$ : 0.25 [silica gel, 4:1 $\mathrm{CHCl}_{3} / \mathrm{MeOH}$ ]; ${ }^{1} \mathrm{H}$ NMR $\left(600 \mathrm{MHz}, \mathrm{DMSO}-d_{6}\right) \delta 9.58$ (br s, $2 \mathrm{H}, \mathrm{H}_{12}$ and $\left.\mathrm{H}_{15}\right), 8.04$ (br s, $1 \mathrm{H}, \mathrm{H}_{21}$ ), 8.02 (s, $1 \mathrm{H}, \mathrm{H}_{8 \mathrm{Ad}}$ ), 7.983 (s, 1H, $\mathrm{H}_{8} / \mathrm{H}_{19}$ ), 7.975 (s, $\left.1 \mathrm{H}, \mathrm{H}_{8} / \mathrm{H}_{19}\right), 7.67$ (br s, $2 \mathrm{H}, \mathrm{H}_{11}$ and $\left.\mathrm{H}_{16}\right), 7.32$ (s, $4 \mathrm{H}, \mathrm{H}_{13}$ and $\left.\mathrm{H}_{14}\right), 7.16\left(\mathrm{~d}, 2 \mathrm{H}, \mathrm{J}=8.1 \mathrm{~Hz}, \mathrm{H}_{4} / \mathrm{H}_{5}\right), 7.11(\mathrm{~d}$, $2 \mathrm{H}, \mathrm{J}=7.9 \mathrm{~Hz}, \mathrm{H}_{4} / \mathrm{H}_{5}$ ), 6.80 (br s, $2 \mathrm{H}, \mathrm{H}_{6 \mathrm{Ad}}$ ), 6.20 (t, $1 \mathrm{H}$, $\left.\mathrm{J}=5.3 \mathrm{~Hz}, \mathrm{H}_{1}\right), 5.84\left(\mathrm{~d}, 1 \mathrm{H}, \mathrm{J}=6.8 \mathrm{~Hz}, \mathrm{H}_{1^{\prime}}\right), 5.58(\mathrm{~d}, 1 \mathrm{H}, \mathrm{J}=$ $\left.4.7 \mathrm{~Hz}, \mathrm{H}_{3^{\prime}-\mathrm{OH}}\right), 5.50$ (d, $1 \mathrm{H}, \mathrm{J}=6.2 \mathrm{~Hz}, \mathrm{H}_{2^{\prime}-\mathrm{OH}}$ ), 4.72 (dd, $\left.1 \mathrm{H}, \mathrm{J}=11.3,6.1 \mathrm{~Hz}, \mathrm{H}_{2^{\prime}}\right), 4.25\left(\mathrm{~d}, 1 \mathrm{H}, \mathrm{J}=2.0 \mathrm{~Hz}, \mathrm{H}_{4^{\prime}}\right), 4.18$ $\left(\mathrm{m}, 1 \mathrm{H}, \mathrm{H}_{3^{\prime}}\right), 3.51\left(\mathrm{~m}, 4 \mathrm{H}, \mathrm{H}_{10}\right.$ and $\left.\mathrm{H}_{17}\right), 3.49-3.34(\mathrm{~m}, 2 \mathrm{H}$, $\mathrm{H}_{2}$ ), $3.23\left(\mathrm{~m}, 4 \mathrm{H}, \mathrm{H}_{9}\right.$ and $\left.\mathrm{H}_{18}\right), 3.20-3.03\left(\mathrm{~m}, 2 \mathrm{H}, \mathrm{H}_{22}\right)$, $2.77\left(\mathrm{~m}, 4 \mathrm{H}, \mathrm{H}_{3}\right.$ and $\left.\mathrm{H}_{6}\right), 2.35\left(\mathrm{t}, 2 \mathrm{H}, \mathrm{J}=8.0 \mathrm{~Hz}, \mathrm{H}_{7}\right), 1.80$ (s, 3H, H 20 ), 0.97 (t, 3H, J=7.0 Hz, H ${ }_{23}$ ); HRMS (ESI) 
calculated for $\mathrm{C}_{37} \mathrm{H}_{50} \mathrm{~N}_{13} \mathrm{O}_{6} \mathrm{~S}_{2}\left(\mathrm{M}+\mathrm{H}^{+}\right)$: 836.3448 , found: 836.3440 .

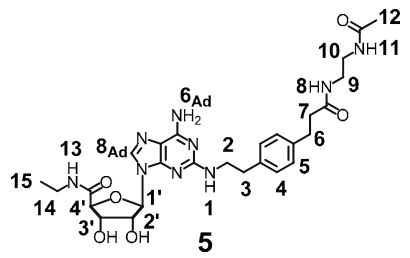

CGS21680 monomeric control 5 CGS21680 4 (6.26 mg, $11.5 \mu \mathrm{mol}$, as a hydrochloride and hemihydrate salt) was dissolved in DMF $(1.00 \mathrm{~mL})$, and DIEA $(9.15 \mu \mathrm{L}$, $52.5 \mu \mathrm{mol})$ was added to this solution. Then $N$-acetylethylenediamine $(4.00 \mu \mathrm{L}, 37.6 \mu \mathrm{mol})$ was added to the stirred mixture, followed by PyBOP $(5.41 \mathrm{mg}, 10.4 \mu \mathrm{mol})$ in one portion as a solid. The reaction was stirred for $18 \mathrm{~h}$ at room temperature, the solvent was removed in vacuo, and the crude product was purified by preparative TLC $\left(5: 1 \mathrm{CHCl}_{3} /\right.$ $\mathrm{MeOH})$ to give $0.88 \mathrm{mg}(1.51 \mu \mathrm{mol}, 15 \%)$ of $\mathbf{5}$ as a white solid. Low yield of this reaction could be due to the highly polar nature of the desired compound $\mathbf{5}$, which was difficult to completely recover from the silica gel. $R_{\mathrm{f}}: 0.28$ [silica gel, 4:1 $\left.\mathrm{CHCl}_{3} / \mathrm{MeOH}\right] ;{ }^{1} \mathrm{H}$ NMR (600 MHz, DMSO- $\left.d_{6}\right) \delta 8.04$ (br s, $\left.1 \mathrm{H}, \mathrm{H}_{13}\right), 8.02$ (s, $\left.1 \mathrm{H}, \mathrm{H}_{8 \mathrm{Ad}}\right), 7.87$ (t, $1 \mathrm{H}, \mathrm{J}=5.2 \mathrm{~Hz}$, $\left.\mathrm{H}_{8}\right), 7.83\left(\mathrm{t}, 1 \mathrm{H}, \mathrm{J}=5.1 \mathrm{~Hz}, \mathrm{H}_{11}\right), 7.15\left(\mathrm{~d}, 2 \mathrm{H}, \mathrm{J}=7.8 \mathrm{~Hz}, \mathrm{H}_{4} /\right.$ $\mathrm{H}_{5}$ ), 7.11 (d, $\left.2 \mathrm{H}, \mathrm{J}=8.4 \mathrm{~Hz}, \mathrm{H}_{4} / \mathrm{H}_{5}\right), 6.79$ (br s, $2 \mathrm{H}, \mathrm{H}_{6 \mathrm{Ad}}$ ), $6.20\left(\mathrm{t}, 1 \mathrm{H}, \mathrm{J}=5.3 \mathrm{~Hz}, \mathrm{H}_{1}\right), 5.84\left(\mathrm{~d}, 1 \mathrm{H}, \mathrm{J}=6.8 \mathrm{~Hz}, \mathrm{H}_{1^{\prime}}\right), 5.58$ (d, $\left.1 \mathrm{H}, \mathrm{J}=4.1 \mathrm{~Hz}, \mathrm{H}_{3^{\prime}-\mathrm{OH}}\right), 5.50\left(\mathrm{~d}, 1 \mathrm{H}, \mathrm{J}=6.3 \mathrm{~Hz}, \mathrm{H}_{2^{\prime}-\mathrm{OH}}\right.$ ), $4.72\left(\mathrm{dd}, 1 \mathrm{H}, \mathrm{J}=11.7,6.3 \mathrm{~Hz}, \mathrm{H}_{2^{\prime}}\right), 4.25(\mathrm{~d}, 1 \mathrm{H}, \mathrm{J}=2.3 \mathrm{~Hz}$, $\left.\mathrm{H}_{4^{\prime}}\right), 4.18\left(\mathrm{~m}, 1 \mathrm{H}, \mathrm{H}_{3^{\prime}}\right), 3.49-3.35\left(\mathrm{~m}, 2 \mathrm{H}, \mathrm{H}_{2}\right), 3.20-3.04$ (m, 2H, $\left.\mathrm{H}_{14}\right), 3.05\left(\mathrm{~m}, 4 \mathrm{H}, \mathrm{H}_{9}\right.$ and $\left.\mathrm{H}_{10}\right), 2.76\left(\mathrm{~m}, 4 \mathrm{H}, \mathrm{H}_{3}\right.$ and $\left.\mathrm{H}_{6}\right), 2.33\left(\mathrm{t}, 2 \mathrm{H}, \mathrm{J}=8.1 \mathrm{~Hz}, \mathrm{H}_{7}\right), 1.78\left(\mathrm{~s}, 3 \mathrm{H}, \mathrm{H}_{12}\right), 0.97$ (t, $3 \mathrm{H}, \mathrm{J}=7.3 \mathrm{~Hz}, \mathrm{H}_{15}$ ); HRMS (ESI) calculated for $\mathrm{C}_{27} \mathrm{H}_{38} \mathrm{~N}_{9} \mathrm{O}_{6}\left(\mathrm{M}+\mathrm{H}^{+}\right)$: 584.2945, found: 584.3066.
PAMAM-DITC-APEC conjugate $10 \mathrm{~A}$ ca. $2.39 \mathrm{mM}$ solution of 7 [22] in DMSO $(560 \mu \mathrm{L}, 1.34 \mu \mathrm{mol})$ was diluted with DMSO $(240 \mu \mathrm{L})$, and DIEA $(10.0 \mu \mathrm{L}, 57.4 \mu \mathrm{mol})$ was added to this stirred solution. Subsequently, a $6.51 \mathrm{mM}$ solution of 5-carboxyfluorescein succinimidyl ester $\mathbf{8}$ in DMSO $(200 \mu \mathrm{L}, 1.30 \mu \mathrm{mol})$ was slowly added. The reaction was protected from light and stirred for $48 \mathrm{~h}$ at room temperature to make 9. A portion of this crude solution of $9(480 \mu \mathrm{L}, 0.643 \mu \mathrm{mol}$, ca. $1.34 \mathrm{mM})$ was transferred into another flask, and a $44.1 \mathrm{mM}$ solution of DITC-APEC 2 in DMSO $(130 \mu \mathrm{L}, 5.73 \mu \mathrm{mol})$ was slowly added to this stirred mixture. The reaction was stirred for 5 days protected from light, purified by SEC (H $36.5 \mathrm{~cm} \times$ O.D. $4.5 \mathrm{~cm}$ ) in DMF, and dried in vacuo to give $\mathbf{1 0}$ as an orange glassy solid. ${ }^{1} \mathrm{H}$ NMR $\left(600 \mathrm{MHz}, \mathrm{DMSO}-d_{6}\right) \delta$ 7.36, 7.32 (br s (each), 18.64H, $\mathrm{H}_{13}$ and $\mathrm{H}_{14}$ ), 7.14, 7.12 (d (each), $20.89 \mathrm{H}, \mathrm{H}_{4}$ and $\mathrm{H}_{5}$ ), 6.80 (br s, 9.36H, $\mathrm{H}_{6 \mathrm{Ad}}$ ), 6.20 $\left(\mathrm{s}, 5.07 \mathrm{H}, \mathrm{H}_{1}\right), 5.84\left(\mathrm{~d}, 4.76 \mathrm{H}, \mathrm{J}=6.2 \mathrm{~Hz}, \mathrm{H}_{1^{\prime}}\right), 4.72(\mathrm{~m}$, $\left.4.42 \mathrm{H}, \mathrm{H}_{2^{\prime}}\right), 4.26\left(\mathrm{~s}, 5.12 \mathrm{H}, \mathrm{H}_{4^{\prime}}\right), 4.19\left(\mathrm{~s}, 4.82 \mathrm{H}, \mathrm{H}_{3^{\prime}}\right), 2.77$ (m, 26.71 $\mathrm{H}, \mathrm{H}_{3}$ and $\left.\mathrm{H}_{6}\right), 2.64\left(\mathrm{~m}, 120.47 \mathrm{H}, \mathrm{H}_{\mathrm{b}}\right.$ and $\mathrm{H}_{\mathrm{g}}$ ), $2.42\left(\mathrm{~m}, 51.65 \mathrm{H}, \mathrm{H}_{\mathrm{e}}\right.$ and $\left.\mathrm{H}_{\mathrm{a}}\right), 2.35\left(\mathrm{~m}, 17.48 \mathrm{H}, \mathrm{H}_{7}\right), 2.18$ $\left(\mathrm{m}, 120.00 \mathrm{H}, \mathrm{H}_{\mathrm{c}}\right), 1.79\left(\mathrm{~s}, 41.15 \mathrm{H}, \mathrm{H}_{\mathrm{h}}\right), 0.97(\mathrm{t}, 14.60 \mathrm{H}, \mathrm{J}=$ $\left.6.7 \mathrm{~Hz}, \mathrm{H}_{18}\right)$.

PAMAM-DITC-APEC conjugate $12 \mathrm{~A}$ ca. $2.68 \mathrm{mM}$ solution of 6 in DMSO $(270 \mu \mathrm{L}, 0.724 \mu \mathrm{mol})$ was diluted with DMSO $(160 \mu \mathrm{L})$, and DIEA $(10.0 \mu \mathrm{L}, 57.4 \mu \mathrm{mol})$ was added to this stirred solution. Subsequently, a $6.51 \mathrm{mM}$ solution of 5-carboxyfluorescein succinimidyl ester 8 in DMSO $(110 \mu \mathrm{L}, 0.716 \mu \mathrm{mol})$ was slowly added. The reaction was protected from light and stirred for $48 \mathrm{~h}$ at room temperature to make 11. A portion of this crude solution of $11(250 \mu \mathrm{L}, 0.335 \mu \mathrm{mol}$, ca. $1.34 \mathrm{mM})$ was transferred into another flask, and a $44.1 \mathrm{mM}$ solution of DITC-APEC 2 in DMSO $(350 \mu \mathrm{L}, 15.4 \mu \mathrm{mol})$ was slowly added to this stirred mixture. The reaction was stirred for 5 days protected from light, purified by SEC (H $39 \mathrm{~cm} \times \mathrm{O}$. D. $3.0 \mathrm{~cm}$ ) in DMF, and dried in vacuo to give $\mathbf{1 2}$ as an orange glassy solid. ${ }^{1} \mathrm{H}$ NMR peak assignments were made

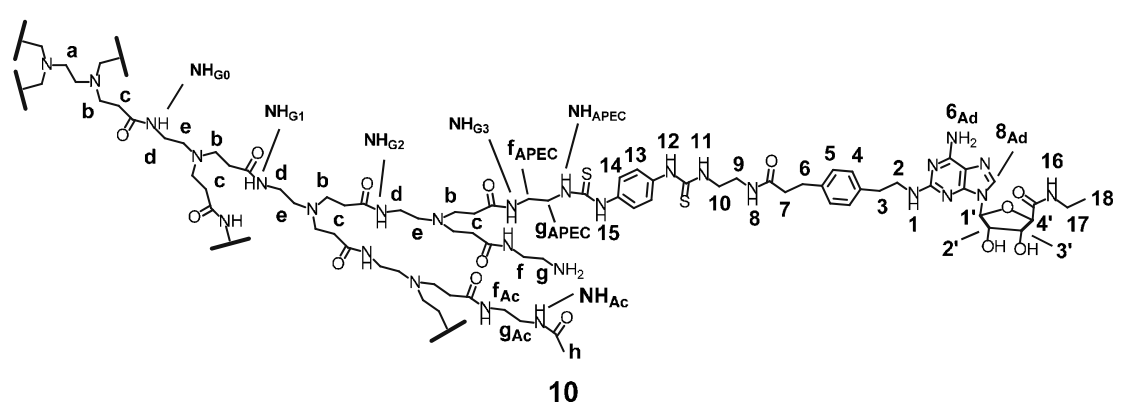


analogous to the labeling method shown for $\mathbf{1 0}$ previously. ${ }^{1} \mathrm{H}$ NMR (600 MHz, DMSO- $\left.d_{6}\right) \delta 7.35,7.32$ (br s (each), $113.53 \mathrm{H}, \mathrm{H}_{13}$ and $\left.\mathrm{H}_{14}\right), 7.14,7.10$ (d (each), $117.93 \mathrm{H}, \mathrm{H}_{4}$ and $\left.\mathrm{H}_{5}\right), 6.81$ (br s, $\left.48.03 \mathrm{H}, \mathrm{H}_{6 \mathrm{Ad}}\right), 6.19\left(\mathrm{~s}, 29.61 \mathrm{H}, \mathrm{H}_{1}\right)$, $5.85\left(\mathrm{~d}, 29.58 \mathrm{H}, \mathrm{J}=6.6 \mathrm{~Hz}, \mathrm{H}_{1^{\prime}}\right), 5.63,5.57$ [br s (each), $52.70 \mathrm{H}, \mathrm{H}_{3^{\prime}-\mathrm{OH}}$ and $\left.\mathrm{H}_{2^{\prime}-\mathrm{OH}}\right], 4.73\left(\mathrm{~m}, 27.32 \mathrm{H}, \mathrm{H}_{2^{\prime}}\right), 4.26(\mathrm{~s}$, $\left.30.11 \mathrm{H}, \mathrm{H}_{4^{\prime}}\right), 4.19\left(\mathrm{~s}, 27.26 \mathrm{H}, \mathrm{H}_{3^{\prime}}\right), 3.24\left(\mathrm{~m}, 119.79 \mathrm{H}, \mathrm{H}_{9}\right.$ and $\left.\mathrm{H}_{\mathrm{fAPEC}}\right), 2.77\left(\mathrm{~m}, 120.73 \mathrm{H}, \mathrm{H}_{3}\right.$ and $\left.\mathrm{H}_{6}\right), 2.66(\mathrm{~m}$, $\left.90.20 \mathrm{H}, \mathrm{H}_{\mathrm{b}}\right), 2.43\left(\mathrm{~m}, 46.27 \mathrm{H}, \mathrm{H}_{\mathrm{e}}\right.$ and $\left.\mathrm{H}_{\mathrm{a}}\right), 2.35(\mathrm{~m}$, $\left.72.28 \mathrm{H}, \mathrm{H}_{7}\right), 2.21\left(\mathrm{~m}, 120.00 \mathrm{H}, \mathrm{H}_{\mathrm{c}}\right), 0.96(\mathrm{t}, 92.42 \mathrm{H}, \mathrm{J}=$ $\left.6.9 \mathrm{~Hz}, \mathrm{H}_{18}\right)$.

PAMAM-DITC-APEC conjugate $13 \mathrm{~A}$ ca. $2.68 \mathrm{mM}$ solution of 6 in DMSO $(162 \mu \mathrm{L}, 0.434 \mu \mathrm{mol})$ was diluted with DMSO $(160 \mu \mathrm{L})$, and DIEA $(10.0 \mu \mathrm{L}, 57.4 \mu \mathrm{mol})$ was added to this stirred solution. Subsequently, a $44.1 \mathrm{mM}$ solution of DITC-APEC 2 in DMSO $(450 \mu \mathrm{L}, 19.8 \mu \mathrm{mol})$ was slowly added to this stirred mixture. The reaction was stirred for 7 days protected from light, purified by SEC (H $36.5 \mathrm{~cm} \times$ O.D. $4.5 \mathrm{~cm}$ ) in DMF, and dried in vacuo to give $\mathbf{1 3}$ as a white glassy solid. ${ }^{1} \mathrm{H}$ NMR peak assignments were made analogous to the labeling method shown for $\mathbf{1 0}$ previously. ${ }^{1} \mathrm{H}$ NMR $\left(600 \mathrm{MHz}, \mathrm{DMSO}-d_{6}\right) \delta 7.35,7.32$ (br s (each), 108.57H, $\mathrm{H}_{13}$ and $\mathrm{H}_{14}$ ), 7.14, 7.10 (d (each), $114.32 \mathrm{H}, \mathrm{J}=7.7 \mathrm{~Hz}, \mathrm{H}_{4}$ and $\mathrm{H}_{5}$ ), $6.80\left(\right.$ br s, $48.57 \mathrm{H}, \mathrm{H}_{6 \mathrm{Ad}}$ ), $6.19\left(\mathrm{~s}, 22.97 \mathrm{H}, \mathrm{H}_{1}\right), 5.84\left(\mathrm{~d}, 25.63 \mathrm{H}, \mathrm{J}=7.2 \mathrm{~Hz}, \mathrm{H}_{1^{\prime}}\right), 5.64$, 5.58 [br s (each), $48.16 \mathrm{H}, \mathrm{H}_{3^{\prime}-\mathrm{OH}}$ and $\mathrm{H}_{2^{\prime}-\mathrm{OH}}$ ], 4.72 $\left(\mathrm{m}, 26.09 \mathrm{H}, \mathrm{H}_{2^{\prime}}\right), 4.26\left(\mathrm{~s}, 27.57 \mathrm{H}, \mathrm{H}_{4^{\prime}}\right), 4.19(\mathrm{~s}, 31.08 \mathrm{H}$, $\left.\mathrm{H}_{3^{\prime}}\right), 2.35\left(\mathrm{~m}, 76.95 \mathrm{H}, \mathrm{H}_{7}\right), 2.20\left(\mathrm{~m}, 120.00 \mathrm{H}, \mathrm{H}_{\mathrm{c}}\right), 0.96$ (t, $\left.86.75 \mathrm{H}, \mathrm{J}=6.9 \mathrm{~Hz}, \mathrm{H}_{18}\right)$.

Radioligand membrane binding experiments Radioligand binding assays were performed for $\mathrm{A}_{1}, \mathrm{~A}_{2 \mathrm{~A}}$, and $\mathrm{A}_{3} \mathrm{ARs}$ as described [23]. Each tube in the binding assay contained $100 \mu \mathrm{L}$ of membrane suspension ( $20 \mu \mathrm{g}$ of protein), $50 \mu \mathrm{L}$ of agonist radioligand, and $50 \mu \mathrm{L}$ of increasing concentrations of the test ligands in Tris-HCl buffer $(50 \mathrm{mM}, \mathrm{pH}$ 7.5) containing $10 \mathrm{mM} \mathrm{MgCl}$. For the initial dissolution, the dendrimer conjugate was heated in the buffer $\left(80^{\circ} \mathrm{C}\right.$ for $1 \mathrm{~h})$. Nonspecific binding was determined using $10 \mu \mathrm{M} \mathrm{5'-}$ $\mathrm{N}$-ethylcarboxamidoadenosine diluted with the buffer. The mixtures were incubated at $25^{\circ} \mathrm{C}$ for $60 \mathrm{~min}$. Binding reactions were terminated by filtration through Whatman GF/B filters under reduced pressure using a MT-24 cell harvester (Brandell, Gaithersburg, MD). Filters were washed three times with $5 \mathrm{~mL}$ of $50 \mathrm{mM}$ ice-cold Tris$\mathrm{HCl}$ buffer ( $\mathrm{pH}$ 7.5). For $\mathrm{A}_{3} \mathrm{AR}$, the agonist radioligand $\left[{ }^{125} \mathrm{I}\right] N^{6}$-(4-amino-3-iodobenzyl)adenosine-5' $-N$-methyluronamide $(0.5 \mathrm{nM})$ was used. After the filters were washed, the radioactivity was measured using a Beckman $\gamma$-counter. For the $A_{1}$ and $A_{2 A}$ assays, the radioactive agonists $\left[{ }^{3} \mathrm{H}\right] 2$ chloro- $N^{6}$-cyclopentyladenosine and $\left[{ }^{3} \mathrm{H}\right] 2-(4-(2-$ carboxyethyl)phenylethylamino)-5'-N-ethylcarboxamido-adeno- sine were used, respectively. After the filters were washed, they were placed in scintillation vials containing $5 \mathrm{~mL}$ of Hydrofluor scintillation buffer and counted using a Perkin Elmer liquid scintillation counter. The $K_{\mathrm{i}}$ values were determined using Prism (GraphPad) for all assays.

Measurement of functional AR activity An assay of cyclic AMP accumulation in response to activation of the human $\mathrm{A}_{2 \mathrm{~A}} \mathrm{AR}$ expressed in $\mathrm{CHO}$ cells was performed as reported [24].

CHO cells stably expressing the human $\mathrm{A}_{3}$ receptor were grown in Dulbecco's Modified Eagle Medium/F12 (Sigma) supplemented with $10 \%$ fetal bovine serum, antibiotics, and glutamine. Each assay was completed by passaging the $\mathrm{CHO} \mathrm{A}_{3}$ cells into 96-well plates and incubating overnight at $37^{\circ} \mathrm{C}$ with $5 \% \mathrm{CO}_{2}$. The FLIPR Calcium 4 Kit provided by Molecular Devices was used as described previously [25]. Briefly, the media was removed from the cells, and $30 \mu \mathrm{L}$ of the Calcium 4 fluorescent dye supplemented with $2.5 \mathrm{mM}$ probenecid was added to each well. The cells were incubated at room temperature for $45 \mathrm{~min}$. The plate was prepared by diluting each compound to $10^{-5}$ to $10^{-9} \mathrm{M}$ in Hanks Buffer. Samples were run in duplicate on the Molecular Devices FlexStation I at room temperature. Cellular fluorescence (excitation at $485 \mathrm{~nm}$; emission at $525 \mathrm{~nm}$ ) was monitored following exposure to the compound. Increases in the intracellular calcium level were reported as the relative fluorescence intensity after the exposure subtracting the basal fluorescence value before the exposure. Each experiment was repeated at least three times. The $\mathrm{EC}_{50}$ value for each compound was calculated using Prism (GraphPad).

Preparation of human washed platelets Human washed platelets were prepared as previously described [26]. Briefly, fresh blood obtained from healthy donors was centrifuged at $175 \times \mathrm{g}$ for $15 \mathrm{~min}$ at $37^{\circ} \mathrm{C}$. Platelet-rich plasma was removed and centrifuged at $1,570 \times \mathrm{g}$ for $15 \mathrm{~min}$ at $37^{\circ} \mathrm{C}$. The platelet pellet was washed twice in Tyrode's buffer $(137 \mathrm{mM} \mathrm{NaCl}, 2 \mathrm{mM} \mathrm{KCl}, 12 \mathrm{mM} \mathrm{NaHCO}$, $0.3 \mathrm{mM} \mathrm{NaH}{ }_{2} \mathrm{PO}_{4}, 1 \mathrm{mM} \mathrm{MgCl} 2,2 \mathrm{mM} \mathrm{CaCl}_{2}, 5.5 \mathrm{mM}$ glucose, $5 \mathrm{mM}$ Hepes, $\mathrm{pH} 7.3$ ) containing $0.35 \%$ human serum albumin, and finally resuspended at a density of $3 \times$ $10^{5}$ platelets $/ \mu \mathrm{L}$ in the same buffer in the presence of $0.02 \mathrm{U} / \mathrm{mL}$ of the ADP scavenger apyrase (adenosine 5'triphosphate diphosphohydrolase, EC 3.6.1.5), a concentration sufficient to prevent desensitization of platelet ADP receptors during storage. Platelets were kept at $37^{\circ} \mathrm{C}$ throughout all experiments.

Platelet aggregation studies Aggregation was measured at $37^{\circ} \mathrm{C}$ by a turbidimetric method in a dual-channel Payton aggregometer (Payton Associates, Scarborough, Ontario, 
Canada). A $450 \mathrm{uL}$ aliquot of platelet suspension was stirred at 1,100 rpm and activated by addition of ADP in the presence or absence of the dendrimer derivative and in the presence of human fibrinogen $(0.8 \mathrm{mg} / \mathrm{mL})$ in a final volume of $500 \mu \mathrm{L}$. The extent of aggregation was estimated quantitatively by measuring the maximum curve height above baseline level. For the antagonist experiment, platelets were incubated with the potent and selective $\mathrm{A}_{2 \mathrm{~A}}$ AR antagonist SCH442416 $(10 \mu \mathrm{M})$ for $5 \mathrm{~min}$, or with $\mathbf{1 0}$ $(1 \mu \mathrm{M})$ for $5 \mathrm{~min}$, or with $\mathrm{SCH} 442416(10 \mu \mathrm{M})(5 \mathrm{~min})$ followed by $\mathbf{1 0}(5 \mathrm{~min})$, and then stimulated with ADP $5 \mu \mathrm{M}$.

Fluorescent confocal microscopy analysis Human washed platelets $\left(3 \times 10^{5}\right.$ platelets $\left./ \mu \mathrm{L}\right)$ resuspended in Tyrode's buffer containing $0.35 \%$ albumin were incubated for increasing periods of time $(5,15,30$, or $60 \mathrm{~min})$ with the dendrimer (as a DMSO solution) or with pure DMSO. Platelets were then washed, resuspended in the same buffer and fixed with paraformaldehyde 2\%. Platelets were then seeded on poly-L-lysine-coated glass coverslips. After washing, the coverslips were mounted in Mowiol 4-88 and examined under a Leica laser confocal scanning microscope (Leica SP5) equipped with a planar apo oil immersion lens $(\times 63$, n.a. $=1.4$, or $\times 100$, n.a. $=$ $1.3)$.

\section{Results and discussion}

Our strategy for the development of dendrimer-based macromolecular signaling agents began by first preparing a monomeric analogue 3 that closely mimics the dendrimerattached form of DITC-APEC (Scheme 1). This structural analogue served as a monomeric control for comparison to the dendrimer conjugates in pharmacological assays. DITCAPEC 2 [20] possesses a reactive isothiocyanate terminus, which will readily react with any free amino or thiol groups, including those on proteins, to form a covalent linkage. Therefore, we chose an ethylenediamine (ED)similar to the PAMAM periphery-capped with an acetyl group on one end to react with DITC-APEC 2 and to convert to the neutral analogue $\mathbf{3}$. The ${ }^{1} \mathrm{H}$ NMR peaks of $\mathbf{3}$ were fully assigned (Fig. S1B, Supporting Information) with the aid of 2D COSY and NOESY experiments, which were later used to easily distinguish the spectral peaks of its dendrimer conjugates and to determine the stoichiometry of ligand attachment by integration.

Recently, we reported on the preparation of G3 PAMAM dendrimer conjugates loaded with multiple copies of CGS21680 and observed the agonistic effects at the human $\mathrm{A}_{2 \mathrm{~A}} \mathrm{AR}$ to inhibit platelet aggregation [17]. APEC is reported to have a higher binding affinity than CGS21680 at the human $\mathrm{A}_{2 \mathrm{~A}} \mathrm{AR}$, despite its known nonselectivity between human $A_{2 A}$ and $A_{3}$ ARs [14]. In order to better predict and compare the effects of these ligands following covalent attachment to the dendrimer surface, a similar analogue of CGS21680, 5, was prepared through a PyBOPmediated amide coupling (Scheme 2).

Next, DITC-APEC units were attached to the G3 PAMAM dendrimers (Scheme 3). Our design principle for dendrimer conjugates involved: (1) preparation of conjugates with both low- and high-loading of DITC-APEC, (2) attachment of a fluorophore, and (3) application of surface modification of residual amines by acetylation in dendrimers having a low degree of DITC-APEC substitution. Despite the facile conjugation chemistry for the attachment of various peripheral groups and their popularity as potential gene delivery vehicles, amine-terminated PAMAM dendrimers are known to be significantly toxic in biological applications [27-29]. Partial acetylation can

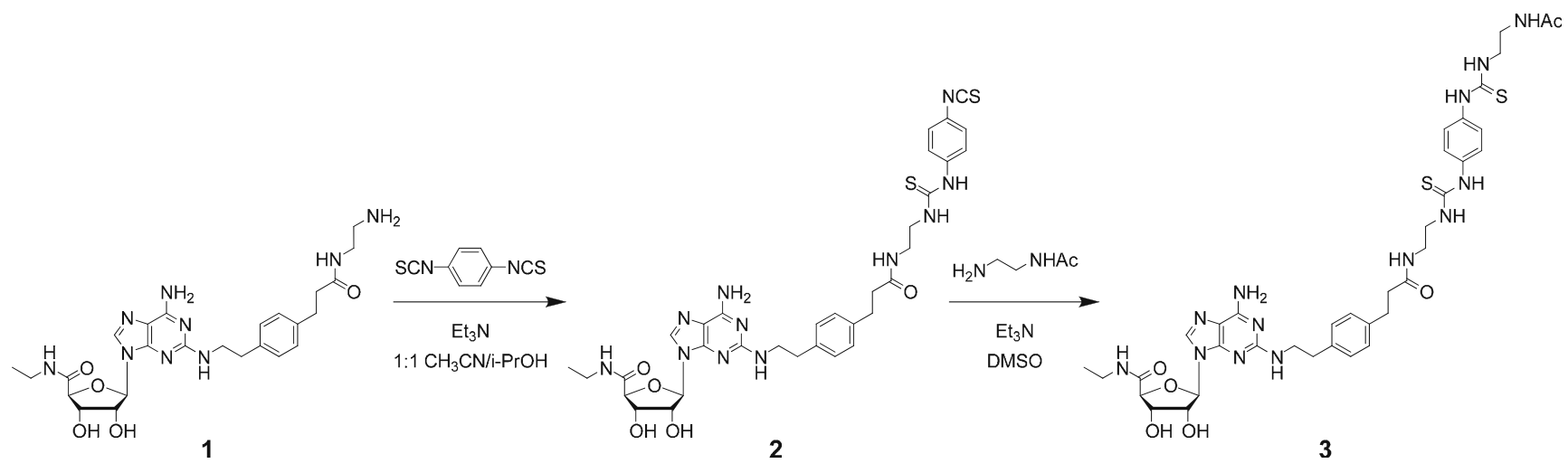

Scheme 1 Synthesis of a DITC-APEC derivative $\mathbf{3}$ as a monomeric control 
Scheme 2 Synthesis of a CGS21680 derivative $\mathbf{5}$ as a monomeric control

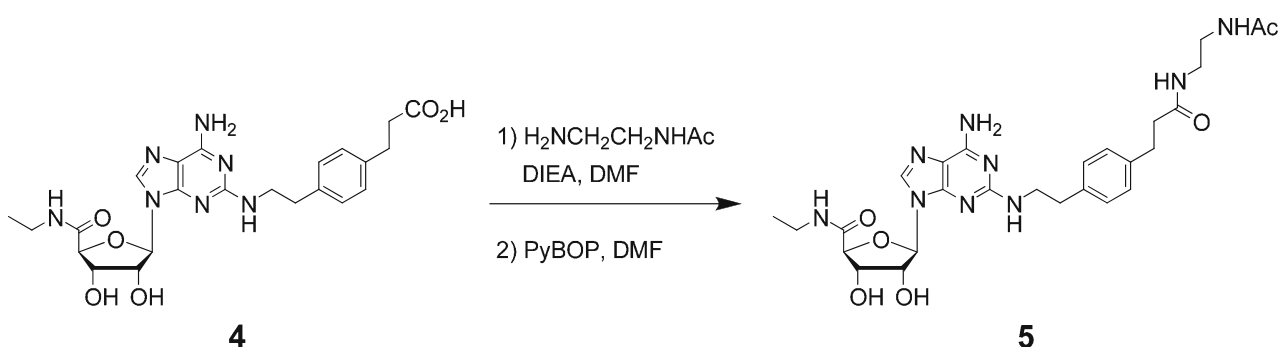

both reduce toxicity $[30,31]$ and enhance the watersolubility of PAMAM dendrimers loaded with various pendant groups [32, 33]. Accordingly, we prepared the dendrimer conjugate $\mathbf{1 0}$ with a low degree of DITC-APEC substitution starting from the partially acetylated dendrimer 7, which was estimated to contain 14 acetamide groups out of 32 available peripheral amino groups by NMR analysis [22]. To a known concentration of 7 in DMSO, an equimolar amount of fluorescein 5-carboxysuccinimide ester was added to yield dendrimer 9. Estimation of the degree of fluorescein substitution by the ${ }^{1} \mathrm{H}$ NMR integration method was not practical due to the relatively low signal intensity compared to the intensity of the PAMAM dendrimer peaks. Thus, on average one equivalent of fluorescein was assumed to be attached to each dendrimer molecule. To this DMSO solution of $\mathbf{9}$, ca. nine equivalents of DITC-APEC 2 were added. The mixture was stirred for
5-7 days and passed through an SEC column (exclusion limit: $14,000 \mathrm{Da}$ ) with DMF as an eluent to collect a pure dendrimer conjugate.

Subsequently, the degree of APEC attachment to the dendrimer was determined by the ${ }^{1} \mathrm{H}$ NMR integration (Fig. S2, Supporting Information). Based on experimental evidence [22], we assumed commercial G3 PAMAM dendrimer 6 to have ca. 32 peripheral groups without any major defects in the structure. Thus, a baseline-separated ${ }^{1} \mathrm{H}$ NMR peak corresponding to a recurring PAMAM methylene near $2.20 \mathrm{ppm}$ ("c", see "Materials and methods" for labeling) was used as an internal standard $(120 \mathrm{H})$, and the relative integration value of a methyl peak at $0.96 \mathrm{ppm}$ (ribose $5^{\prime}$ substitution) was measured. On average, five APEC groups were found to be attached to the dendrimer conjugate through this integration method. Alternatively, quantification of ligand substitution by comparing the
Scheme 3 Synthesis of PAMAM-DITC-APEC dendrimer conjugate $\mathbf{1 0}$

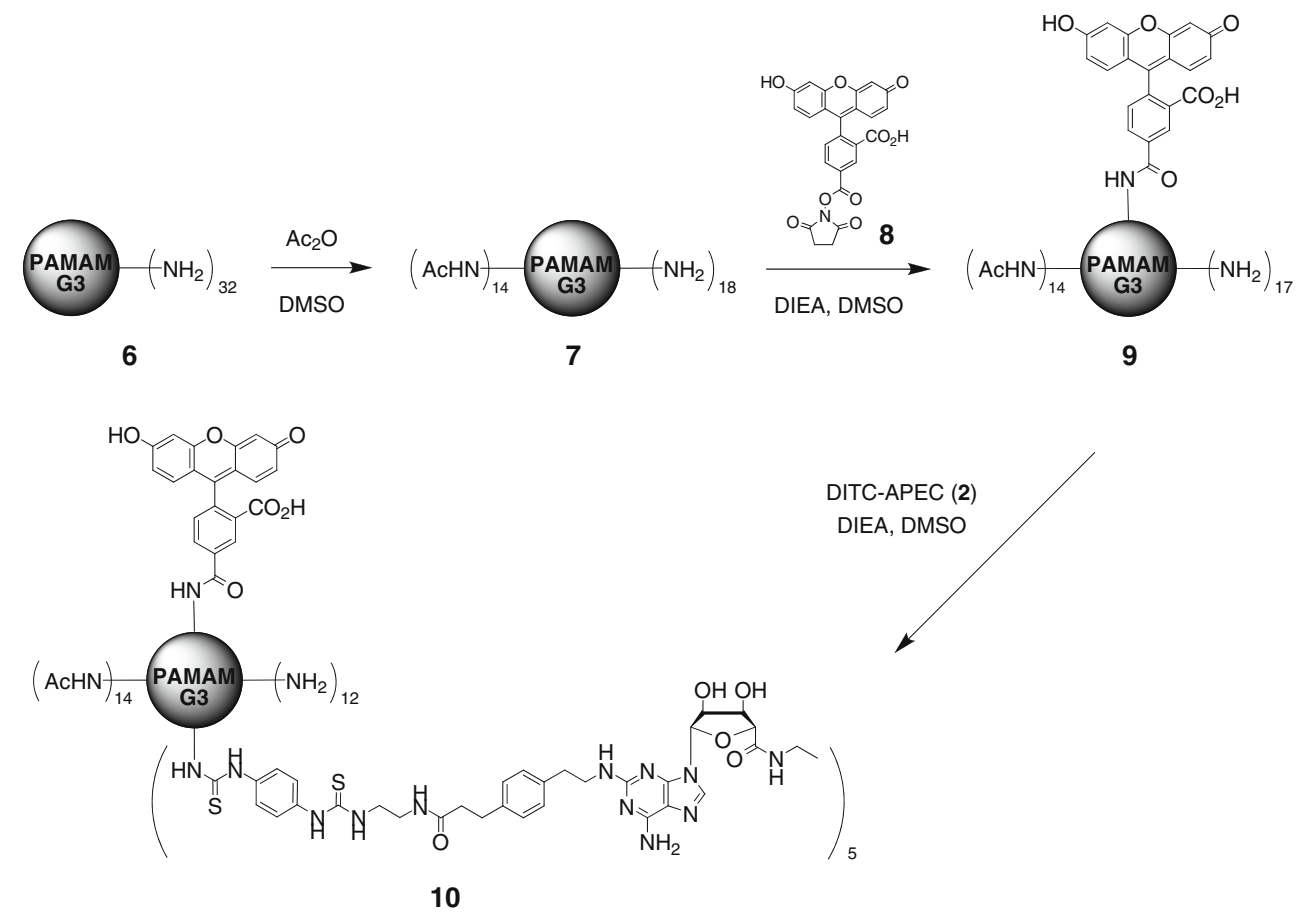




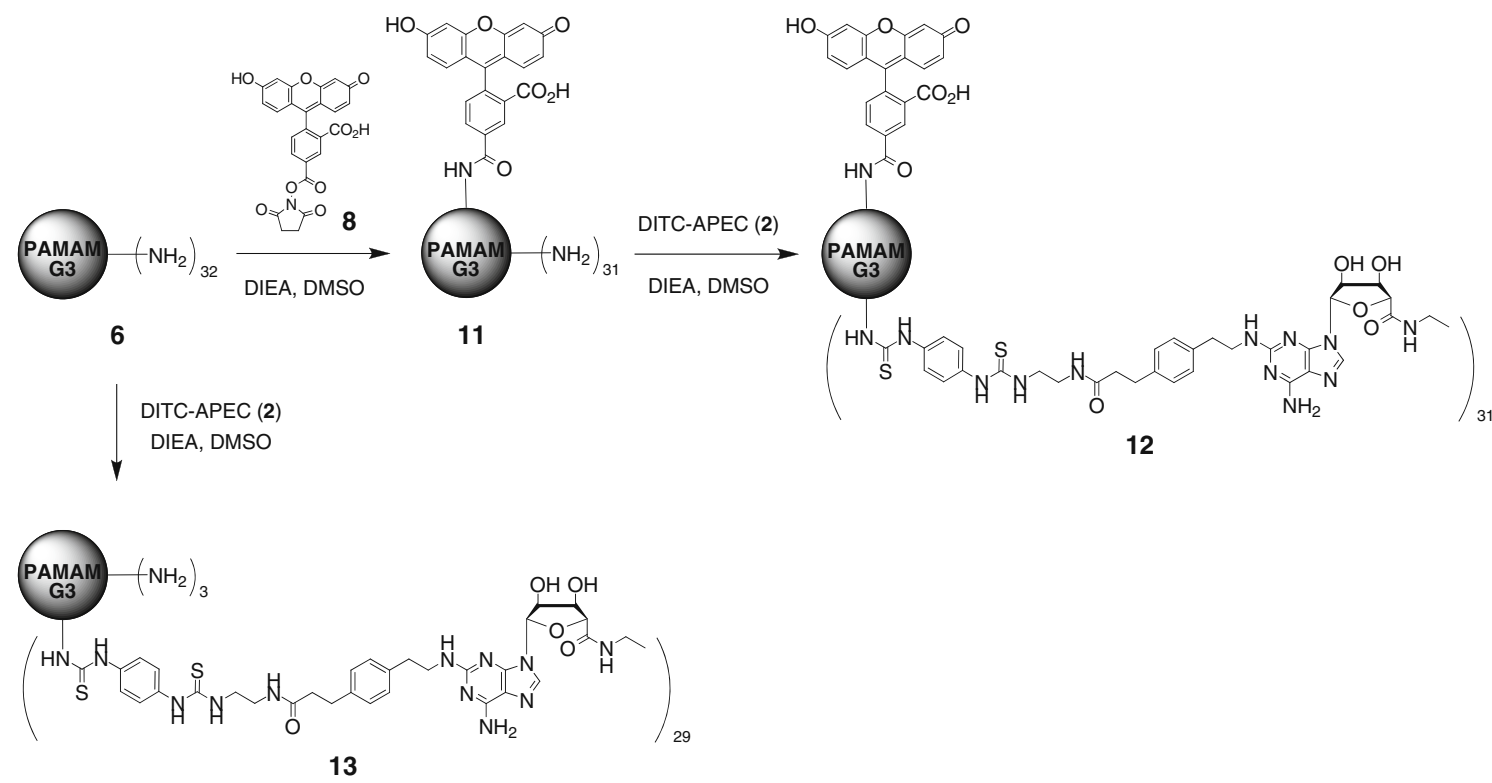

Scheme 4 Synthesis of PAMAM-DITC-APEC dendrimer conjugates 12 and $\mathbf{1 3}$

relative UV absorptions of the monomer and dendrimer $\mathbf{1 0}$ was attempted. Unfortunately, obtaining a reliable UV absorption was difficult due to the limited water-solubility, significant overlap of the adenine and other aromatic absorptions, and the high background absorption near the aromatic region $(260-290 \mathrm{~nm})$ when using DMSO as a solvent.

Similarly, dendrimer conjugates with a high degree of DITC-APEC substitution were prepared (Scheme 4). Excess amount of DITC-APEC $\mathbf{2}$ was added to either the fluorescently labeled G3 PAMAM $\mathbf{1 1}$ or nonfluorescent PAMAM 6. Characterization of the SEC-purified conjugates $\mathbf{1 2}$ and $\mathbf{1 3}$ by ${ }^{1} \mathrm{H}$ NMR was achieved analogously to that for $\mathbf{1 0}$ to have 31 and 29 DITC-APEC attachments, respectively (Figs. S3 and S4, Supporting Information). Interestingly, later we consistently found that all three PAMAM conjugates $-10,12$, and 13 - slowly degraded and lost some of the covalently attached APEC content when repurified by SEC and analyzed by ${ }^{1} \mathrm{H}$ NMR. The degree of decomposition was the highest for dendrimer $\mathbf{1 0}$ which had the lowest ligand substitution. Currently, the mechanism of degradation of the APEC linkage is not fully elucidated; however, the basic amino groups of the PAMAM scaffold likely participate in this unexpected bond cleavage. One possible explanation can be a base-catalyzed degradation of the partially conjugated aromatic bisthiourea moiety to produce aniline and hydrolyzed products of the isothiocyanate groups on either side. ${ }^{1}$

\footnotetext{
${ }^{1}$ Independently, when a monomeric analogue of $\mathbf{3}$ capped with a Boc group (structure not shown) was treated with trifluoroacetic acid, a molecular ion corresponding to the mass of the APEC derivative with the isothiocyanate end group instead of amine was found exclusively in the mass spectrum (Kim Y, Jacobson KA, unpublished results).
}

The size of these dendrimer conjugates was estimated by computer modeling (Fig. 1, HyperChem 7.5.2, Amber force field). The energy-minimized structure of G3 PAMAM with full DITC-APEC substitutions (i.e., 32 ligands) suggested an overall diameter of ca. $80-110 \AA$ with a somewhat ellipsoidal shape [34], similar to the CGS21680 conjugate reported previously [17]. The extension of diameter by ca. $20 \AA$ for the DITC-APEC dendrimer conjugate compared to the CGS21680 dendrimer analogue may afford enhanced conformational flexibility of the linker arms to reach out and benefit in the potential multivalent ligand-receptor interactions. Indeed, this extension of dendrimer diameter closely matched twice the difference of the linker distance predicted by the energy-minimization (PM3) carried out for the fully stretched forms of the monomeric controls $\mathbf{3}$ and $\mathbf{5}$ (Fig. S5, Supporting Information).

In vitro binding and functional assays at human ARs were then performed using the nucleoside-dendrimer conjugates 10, 12, and 13 (Table 1). Three subtypes of human ARs$\mathrm{A}_{1}, \mathrm{~A}_{2 \mathrm{~A}}$, and $\mathrm{A}_{3}$-were stably expressed in either $\mathrm{CHO}$ or HEK-293 cells. Functional assays of the stimulation of adenylate cyclase via the $\mathrm{A}_{2 \mathrm{~A}} \mathrm{AR}$ and calcium mobilization via the $A_{3} A R$ were also performed. Several related monomers, APEC 1, a monomeric control 3 derived from DITC-APEC, CGS21680 4, and a monomeric control 5 derived from CGS21680, were also assayed under the same conditions. First, the monomers were compared for their binding at these three subtypes of ARs. Except for the APEC $\mathbf{1}$, which showed a moderate effect, the three monomers- $\mathbf{3}$, 4, and 5- did not exhibit any significant binding at the $\mathrm{A}_{1}$ AR. APEC, the highest affinity binder at the $\mathrm{A}_{2 \mathrm{~A}} \mathrm{AR}$, had a diminished effect when its distal amino group was either acetylated to form $\mathbf{5}$ or substituted with an end-capped 


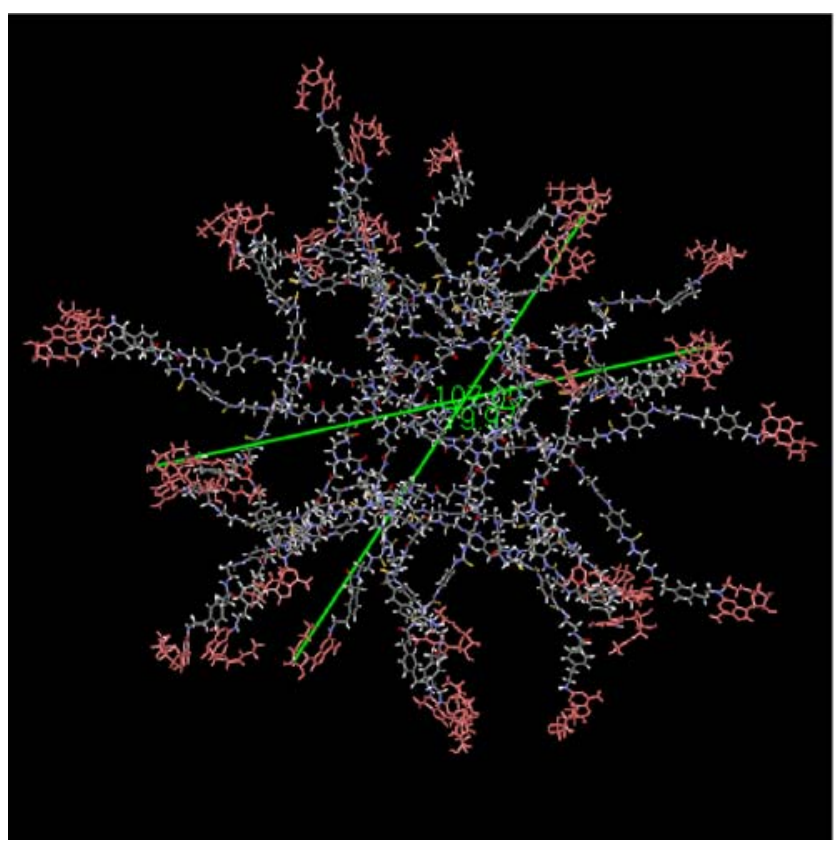

Fig. 1 An energy-minimized structure of a G3-PAMAM dendrimer conjugate having 32 covalently bound DITC-APEC groups (right, analogue of 13). The calculation proceeded using the HyperChem 7.5.2 software through an Amber force field. Terminal adenosine

DITC-ED extension to form 3 . Binding affinity determined at the $\mathrm{A}_{2 \mathrm{~A}} \mathrm{AR}$ for CGS21680 4 lacking the ED unit was similar to the value obtained for 3 ; however, the end-capped CGS21680 monomeric control $\mathbf{5}$ with an ED extension exhibited the lowest affinity. Nonetheless, activation of adenylate cyclase, characteristic of $\mathrm{A}_{2 \mathrm{~A}} \mathrm{AR}$ agonists, by CGS21680 analogue 5 was achieved at a comparable degree to that by CGS21680 4. Here, the chemical structure of the CGS21680 monomeric control $\mathbf{5}$ closely resembles that of APEC 1 except for its distal amino group being capped by an acetyl group. Accordingly, the free amino group of APEC 1 may be the key element in achieving the high binding affinity and potencyat the $A_{2 A} A R$. For $A_{3} A R$, despite the limited available comparisons, APEC 1 showed the highest binding affinity and potency. The binding affinity of APEC at the $A_{3} A R$ was comparable to that at the $A_{2 A} A R$, as reported [14]. The monomeric control 5 derived from CGS21680, which best resembles the structure of APEC but with the end-capping, also displayed a relatively strong affinity at the human $\mathrm{A}_{3}$ AR. However, CGS21680 4 without the ED extension had a significantly lower affinity, suggesting the importance of the ED unit for the $\mathrm{A}_{3} \mathrm{AR}$ recognition. Intriguingly, the actual agonistic effect of CGS21680 control 5 at the $\mathrm{A}_{3} \mathrm{AR}$, measured by the increase in the intracellular calcium concentration, was substantially weaker when compared to that of APEC 1.

Next, the binding affinities of dendrimers at three subtypes of human ARs were determined. The commercial PAMAM dendrimer 6 without any ligand attachments did

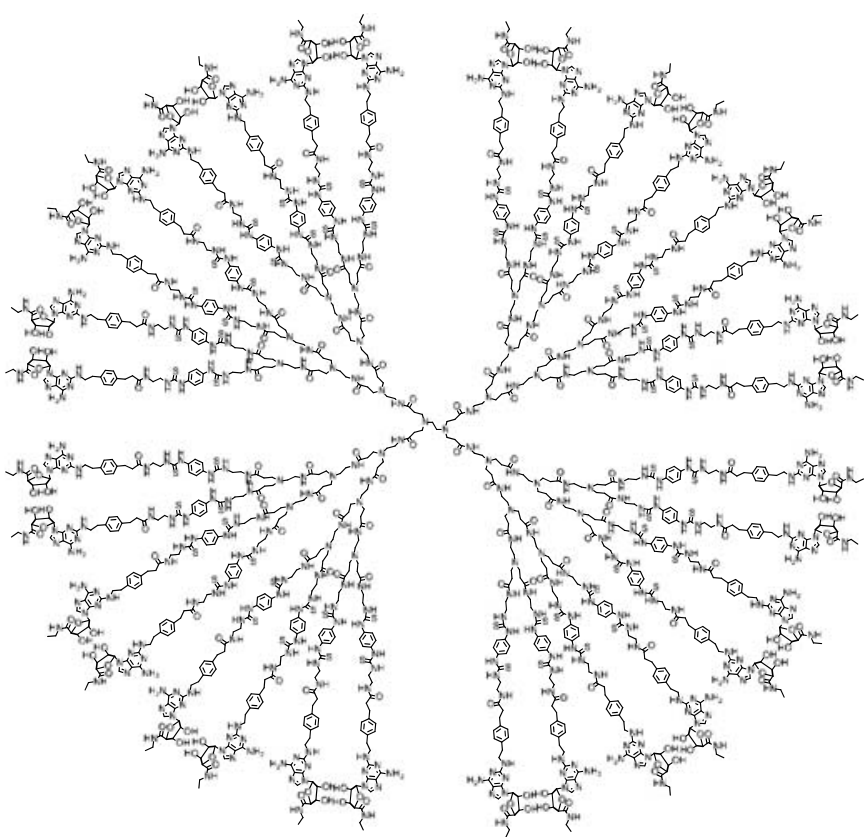

moieties are highlighted in pink for visibility. Overall diameters, ca. 80-110 А, were measured (shown in green) between ligands (C3'-C3' distance of the ribose ring) approximately diagonal to each other through the central core

not show any detectable binding effect at all three ARs tested. Interestingly, the fluorescent dendrimer 9-precursor of 10 - without any ligand slightly inhibited binding at the $A_{3} A R$, but there were no effects at the other AR subtypes. The binding at $\mathrm{A}_{1} \mathrm{AR}$ of all tested dendrimers was negligible. The reduction of nucleoside ligand affinity at the $\mathrm{A}_{1} \mathrm{AR}$ upon its conjugation to the dendrimers indicates an increased preference for the other two receptors, $A_{2 A}$ and $A_{3}$ ARs. Here, the difference in the effects exhibited between dendrimers with high- and lowloading of APEC ligands was minor (i.e., within experimental error). Overall, when compared to the monomeric ligands (e.g., DITC-APEC control 3), attachment of APEC derivatives to PAMAM dendrimer slightly reduced the affinity at $\mathrm{A}_{2 \mathrm{~A}} \mathrm{AR}$ while preserving the binding affinity at the $\mathrm{A}_{3}$ AR. As suggested previously by comparing the monomers, the distal amino group of APEC, which is lacking in the dendrimer-appended form, may be crucial in achieving a potent effect at the $\mathrm{A}_{2 \mathrm{~A}} \mathrm{AR}$. On the other hand, affinity of the APEC derivatives at the $\mathrm{A}_{3} \mathrm{AR}$, which may be improved by the addition of an ED moiety, was not affected by attaching them to the dendrimers. Taken together, the attachment of APEC derivatives to the periphery of a G3 PAMAM dendrimer through an extended linker with a dithioureylenephenyl functionality, may have slightly improved the relative affinity at the $\mathrm{A}_{3} \mathrm{AR}$ compared to $A_{2 A} A R$. Yet, the water-solubility of dendrimer conjugates, especially with high-loading of APEC derivatives 12 and $\mathbf{1 3}$ was relatively low, and further 
Table 1 Radioligand binding $\left(K_{\mathrm{i}}\right)$ results of monomers and dendrimer derivatives at three subtypes of human ARs and functional $\left(E C_{50}\right)$ assay results (stimulation of adenylate cyclase via the $A_{2 A} A R$ and calcium mobilization via the $\left.A_{3} A R\right)^{a}$

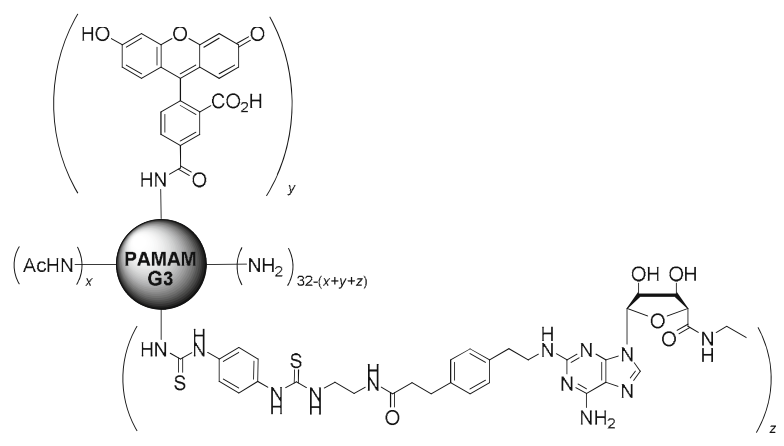

\begin{tabular}{|c|c|c|c|c|c|c|c|c|}
\hline \multirow[t]{2}{*}{ Compound } & \multicolumn{3}{|c|}{ Composition } & \multicolumn{3}{|l|}{$K_{\mathrm{i}}(\mathrm{nM})$} & \multicolumn{2}{|c|}{$E C_{50}(\mathrm{nM})$} \\
\hline & & & & $h \mathrm{~A}_{1}$ & $h \mathrm{~A}_{2 \mathrm{~A}}$ & $h \mathrm{~A}_{3}$ & $h \mathrm{~A}_{2 \mathrm{~A}}$ & $h \mathrm{~A}_{3}$ \\
\hline & \multicolumn{8}{|c|}{ Monomer } \\
\hline 1 & API & & & $168 \pm 36$ & $29 \pm 5$ & $38 \pm 11$ & $8.2 \pm 1.7$ & $170 \pm 90$ \\
\hline 3 & $N-\mathrm{A}$ & $\mathrm{TC}$ & & $840 \pm 100$ & $70 \pm 3$ & n.d. & n.d. & $375 \pm 40$ \\
\hline 4 & $\mathrm{CG}$ & & & $5,780 \pm 590$ & $67 \pm 19$ & $247 \pm 79$ & $53 \pm 16$ & n.d. \\
\hline \multirow[t]{3}{*}{5} & $N-\mathrm{A}$ & & & $984 \pm 223$ & $110 \pm 15$ & $58 \pm 24$ & $51 \pm 8$ & $725 \pm 110$ \\
\hline & \multicolumn{8}{|c|}{ Dendrimer $^{\mathrm{b}}$} \\
\hline & $x$ & $y$ & $z$ & & & & & \\
\hline 6 & 0 & 0 & 0 & n.a. & n.a. & n.a. & n.d. & n.d. \\
\hline 9 & 14 & 1 & 0 & n.a. & n.a. & $(52 \pm 2) \% \%^{\mathrm{c}}$ & n.d. & n.d. \\
\hline 10 & 14 & 1 & 5 & $(36 \pm 13) \%{ }^{\mathrm{c}}$ & $152 \pm 31$ & $42 \pm 5$ & n.d. & n.d. \\
\hline 12 & 0 & 1 & 31 & $(32 \pm 20) \%^{\mathrm{c}}$ & $96 \pm 20$ & $55 \pm 22$ & n.d. & n.d. \\
\hline 13 & 0 & 0 & 29 & $(44 \pm 13) \%^{\mathrm{c}}$ & $130 \pm 16$ & $69 \pm 26$ & n.d. & n.d. \\
\hline
\end{tabular}

n.d. Not determined, i.e., binding (or functional) experiment was not conducted, n.a. not active, i.e., no binding was detected at $\leq 10 \mu \mathrm{M}$

${ }^{a}$ Values are presented as the mean \pm SEM of three or more independent experiments. $\mathrm{A}_{1}$ and $\mathrm{A}_{3} \mathrm{ARs}$ were expressed in CHO cells and $\mathrm{A}_{2 \mathrm{~A}} \mathrm{AR}$ in HEK-293 cells. $K_{\mathrm{i}}$ values are reported for the binding assay, and $E C_{50}$ values are reported for the functional assay

${ }^{\mathrm{b}}$ PAMAM dendrimer 6 was assumed to have 32 peripheral amino groups without any defects in the structure. Number of peripheral attachments ( $x$ for acetamide groups, $z$ for nucleoside units) was determined by the analysis of ${ }^{1} \mathrm{H}$ NMR integration. Number of fluorescein groups $(y)$ was estimated based on the molar equivalents added to the reaction

${ }^{\mathrm{c}}$ Measured as percent inhibition at $10 \mu \mathrm{M}$

improvements in the structural design of our dendritic nanocarrier are necessary for a more accurate evaluation.

To determine the agonistic effects of our fluorescent dendrimer conjugates at the $\mathrm{A}_{2 \mathrm{~A}} \mathrm{AR}$, we then examined their antiaggregatory effect on platelet aggregation [35]. Adenosine and synthetic agonists of the $A_{2 A}$ AR inhibit ADPinduced platelet aggregation. In addition, our previous PAMAM dendrimer conjugate loaded with multiple copies of CGS21680 also manifested an efficient antiaggregatory effect through the activation of $\mathrm{A}_{2 \mathrm{~A}} \mathrm{AR}$ [17]. Here, three fluorescent dendrimers $-\mathbf{9}, \mathbf{1 0}$, and 12-were subjected to in vitro aggregometry using human washed platelets (Fig. 2). Dendrimer 9, which did not contain any APEC derivatives, served as a control. As anticipated, an efficient antiaggrega- tory effect was observed when the platelets were incubated with each of the dendrimer conjugates $\mathbf{1 0}$ or $\mathbf{1 2}$, followed by stimulation with ADP to initiate platelet aggregation. Neither the dendrimer control 9, which contained no covalently attached nucleoside, nor a DMSO control inhibited platelet aggregation. A selective antagonist of the $A_{2 A} A R$, SCH442416 [36], was used to demonstrate that the inhibition of platelet aggregation by dendrimer $\mathbf{1 0}$ occurred through the activation of the $\mathrm{A}_{2 \mathrm{~A}}$ AR. Preapplication of SCH442416 $(10 \mu \mathrm{M})$ had no effect on aggregation induced by $5 \mu \mathrm{M}$ ADP, while it completely reversed the inhibitory effect of 1 $\mu \mathrm{M} 10$ (data not shown).

Interestingly, an efficient internalization into the platelets was detected by fluorescent confocal microscopy only for 


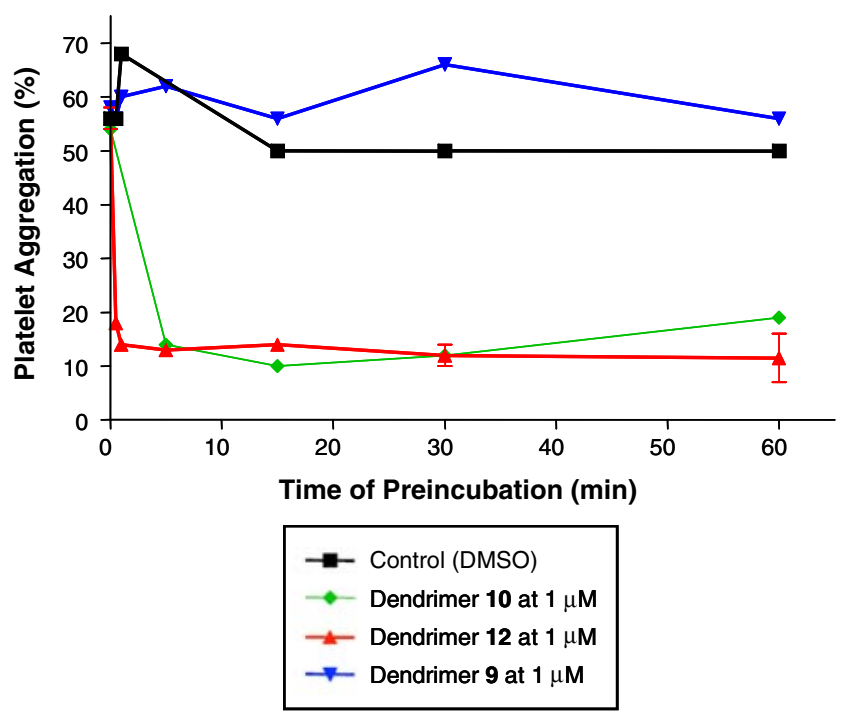

Fig. 2 Platelet aggregation studies at $37^{\circ} \mathrm{C}$ in the presence or absence of dendrimers. A suspension of human washed platelets was incubated for increasing periods of time with DMSO (control) or dendrimers (each dendrimer was added as a DMSO solution), to which ADP was then added to induce platelet aggregation. Each dendrimer was added as a DMSO solution $(5 \mathrm{mM})$ and the final concentration of dendrimers in the media was $1 \mu \mathrm{M}(500 \mu \mathrm{L})$. The total content of DMSO in the media was $0.02 \%(\mathrm{v} / \mathrm{v})$ in all cases. The control was prepared similarly from the DMSO solution without any dendrimer

the control dendrimer 9 (Fig. 3). Other PAMAM dendrimer conjugates, $\mathbf{1 0}$ and 12, bearing APEC derivatives, were not detectably internalized. The fluorescence intensity of fluorescein derivatives is $\mathrm{pH}$-dependent, and thus may be subject to intracellular inactivation, which may affect these results. Indeed, under a confocal microscope, multiple numbers of the individual fluorescent dendrimer molecule 9 were found inside each platelet. Thus, present findings do not support that the internalization of these dendrimer derivatives is AR-mediated, because only the control dendrimer was internalized.

\section{Conclusions}

New dendrimer-based macromolecular therapeutics for GPCRs were prepared by treating the surface amino groups of G3 PAMAM dendrimers with different molar ratios of DITC-APEC, a chemically reactive $\mathrm{A}_{2 \mathrm{~A}} \mathrm{AR}$ agonist. The present study expanded our previous efforts to engineer a similar $\mathrm{A}_{2 \mathrm{~A}}$ AR-specific dendritic nanocarrier, an amidelinked PAMAM-CGS21680 conjugate that retained biological activity. Compared to the CGS21680 dendrimer conjugates, our new dendritic delivery agents described herein aimed to enhance: (1) the conformational flexibility to achieve a favorable geometry for binding at the heptahelical domain of ARs, and (2) the specificity in binding by the added dithioureylenephenyl functionality at the distal unit under the scheme of functionalized congener approach. Affinities of submicromolar $K_{\mathrm{i}}$ values were obtained from the PAMAM-DITC-APEC conjugates at $\mathrm{A}_{2 \mathrm{~A}}$ ARs; however, the selectivity at $A_{3}$ AR slightly increased with regard to the binding profile of small molecule monomers. Furthermore, these PAMAM dendrimers loaded with APEC derivatives displayed an efficient inhibitory effect on platelet aggregation stimulated by $\mathrm{ADP}$, which is characteristic of $\mathrm{A}_{2 \mathrm{~A}} \mathrm{AR}$ agonists. Thus, application of dendrimer technology to the $\mathrm{A}_{2 \mathrm{~A}}$ AR might lead to novel antithrombotic agents.

Acknowledgements This research was supported in part by the Intramural Research Program of the NIH, NIDDK. We thank Dr. Herman Yeh for the helpful advice on the NMR experiments, and Dr. Bhalchandra V. Joshi at NIDDK, NIH, for providing us with 1,4diisothiocyanatobenzene. Y.K. thanks the Can-Fite Biopharma for financial support.
Fig. 3 Fluorescence confocal microscopy of human washed platelets incubated with either dendrimer $9(1 \mu \mathrm{M})$ for $5 \mathrm{~min}$. The fluorescent dendrimer 9 internalized into the platelet is shown as green dots. The total content of DMSO in the media was $0.02 \%(\mathrm{v} / \mathrm{v})$
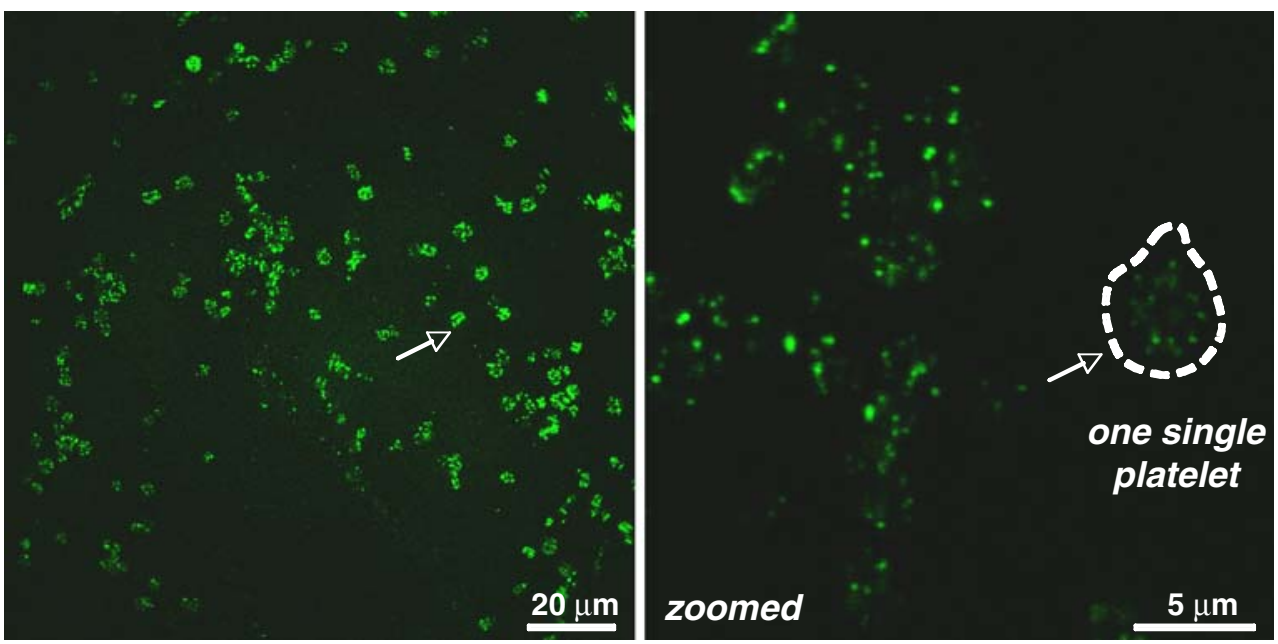


\section{References}

1. Lee CC, MacKay JA, Fréchet JMJ, Szoka FC (2005) Designing dendrimers for biological applications. Nature Biotechnol 23:1517-1526

2. Svenson S, Tomalia DA (2005) Dendrimers in biomedical applications-reflections on the field. Adv Drug Delivery Rev 57:2106-2129

3. Boas U, Heegaard PMH (2004) Dendrimers in drug research. Chem Soc Rev 33:43-63

4. Stiriba S-E, Frey H, Haag R (2002) Dendritic polymers in biomedical applications: from potential to clinical use in diagnostics and therapy. Angew Chem Int Ed 41:1329-1334

5. Tomalia DA (2005) Birth of a new macromolecular architecture: dendrimers as quantized building blocks for nanoscale synthetic polymer chemistry. Prog Polym Sci 30:294-324

6. Grayson SM, Fréchet JMJ (2001) Convergent dendrons and dendrimers: from synthesis to applications. Chem Rev 101:3819-3867

7. Zeng F, Zimmerman SC (1997) Dendrimers in supramolecular chemistry: from molecular recognition to self-assembly. Chem Rev 97:1681-1712

8. Mammen M, Choi S-K, Whitesides GM (1998) Polyvalent interactions in biological systems: implications for design and use of multivalent ligands and inhibitors. Angew Chem Int Ed 37:2754-2794

9. Pin JP, Neubig R, Bouvier M, Devi L, Filizola M, Javitch JA, Lohse MJ, Milligan G, Palczewski K, Parmentier M, Spedding M (2007) International union of basic and clinical pharmacology. LXVII. Recommendations for the recognition and nomenclature of $G$ protein-coupled receptor heteromultimers. Pharmacol Rev 59:5-13

10. Jacobson KA, Daly JW (1991) Purine functionalized congeners as molecular probes for adenosine receptors. Nucleosides and Nucleotides 10:1029-1038

11. Jacobson KA, Kirk KL, Padgett WL, Daly JW (1985) Functionalized congeners of adenosine: preparation of analogues with high affinity for $\mathrm{A}_{1}$-adenosine receptors. J Med Chem 28:1341-1346

12. Landry Y, Niederhoffer N, Sick E, Gies JP (2006) Heptahelical and other G-protein-coupled receptors (GPCRs) signaling. Curr Med Chem 13:51-63

13. Ratnala VR, Kiihne SR, Buda F, Leurs R, de Groot HJ, DeGrip WJ (2007) Solid-state NMR evidence for a protonation switch in the binding pocket of the $\mathrm{H} 1$ receptor upon binding of the agonist histamine. J Am Chem Soc 129:867-872

14. Jacobson KA, Gao Z-G (2006) Adenosine receptors as therapeutic targets. Nature Rev Drug Discovery 5:247-264

15. Yan L, Burbiel JC, Maass A, Müller CE (2003) Adenosine receptor agonists: from basic medicinal chemistry to clinical development. Expert Opin Emerg Drugs 8:537-576

16. Fredholm BB, IJzerman AP, Jacobson KA, Klotz K-N, Linden J (2001) International Union of Pharmacology. XXV. Nomenclature and classification of adenosine receptors. Pharmacol Rev 53:527-552

17. Kim Y, Hechler B, Klutz AM, Gachet C, Jacobson KA (2008) Toward multivalent signaling across $\mathrm{G}$ protein-coupled receptors from poly(amidoamine) dendrimers. Bioconjugate Chem. 19:406411

18. Niiya K, Jacobson KA, Silvia SK, Olsson RA (1993) Covalent binding of a selective agonist irreversibly activates guinea pig coronary artery $\mathrm{A}_{2}$ adenosine receptors. Naunyn-Schmeideberg's Arch Pharamacol 347:521-526

19. Jacobson KA, Stiles GL, Ji X-D (1992) Chemical modification and irreversible inhibition of striatal $\mathrm{A}_{2 \mathrm{a}}$ adenosine receptors. Mol Pharm 42:123-133

20. Jacobson KA, Pannell LK, Ji X-D, Jarvis MF, Williams M, Hutchison AJ, Barrington WW, Stiles G (1989) Agonist derived molecular probes for $\mathrm{A}_{2}$ adenosine receptors. $\mathrm{J}$ Mol Recogn 2:170-178

21. Esfand R, Tomalia DA (2001) Poly(amidoamine) (PAMAM) dendrimers: from biomimicry to drug delivery and biomedical applications. Drug Discovery Today 6:427-436

22. Kim Y, Klutz AM, Jacobson KA (2008) Systematic investigation of polyamidoamine dendrimers surface-modified with poly(ethylene glycol) for drug delivery applications: Synthesis, characterization, and evaluation of cytotoxicity. Bioconjugate Chem 19 (in press)

23. Perreira M, Jiang JK, Klutz AM, Gao Z-G, Shainberg A, Lu C, Thomas CJ, Jacobson KA (2005) "Reversine" and its 2substituted adenine derivatives as potent and selective A3 adenosine receptor antagonists. J Med Chem 48:4910-4918

24. Jacobson KA, Ohno M, Duong HT, Kim SK, Tchilibon S, Cesnek M, Holy A, Gao Z-G (2005) A neoceptor approach to unraveling microscopic interactions between the human $\mathrm{A}_{2 \mathrm{~A}}$ adenosine receptor and its agonists. Chem Biol 12:237-247

25. Niebauer RT, Gao Z-G, Li B, Wess J, Jacobson KA (2005) Signaling of the human $\mathrm{P}_{2} \mathrm{Y}_{1}$ receptor measured by a yeast growth assay with comparisons to assays of phospholipase $\mathrm{C}$ and calcium mobilization in $1321 \mathrm{~N} 1$ human astrocytoma cells. Purinergic Signalling 1:241-247

26. Cazenave JP, Ohlmann P, Cassel D, Eckly A, Hechler B, Gachet C (2004) Preparation of washed platelet suspensions from human and rodent blood. Methods Mol Biol 272:13-28

27. Jevprasesphant R, Penny J, Jalal R, Attwood D, McKeown NB, D'Emanuele A (2003) The influence of surface modification on the cytotoxicity of PAMAM dendrimers. Int J Pharm 252:263-266

28. Fischer D, Li Y, Ahlemeyer B, Krieglstein J, Kissel T (2003) In vitro cytotoxicity testing of polycations: influence of polymer structure on cell viability and hemolysis. Biomaterials 24:1121-1131

29. Malik N, Wiwattanapatapee R, Klopsch R, Lorenz K, Frey H, Weener JW, Meijer EW, Paulus W, Duncan R (2000) Dendrimers: relationship between structure and biocompatibility in vitro, and preliminary studies on the biodistribution of ${ }^{125} \mathrm{I}$ labelled polyamidoamine dendrimers in vivo. J Control Release 65:133-148

30. Kolhatkar RB, Kitchens KM, Swaan PW, Ghandehari H (2007) Surface acetylation of polyamidoamine (PAMAM) dendrimers decreases cytotoxicity while maintaining membrane permeability. Bioconjugate Chem 18:2054-2060

31. Majoros IJ, Keszler B, Woehler S, Bull T, Baker JR Jr (2003) Acetylation of poly(amidoamine) dendrimers. Macromolecules 36:5526-5529

32. Majoros IJ, Thomas TP, Mehta CB, Baker JR Jr (2005) Poly (amidoamine) dendrimer-based multifunctional engineered nanodevice for cancer therapy. J Med Chem 48:5892-5899

33. Quintana A, Raczka E, Piehler L, Lee I, Myc A, Majoros I, Patri AK, Thomas T, Mulé J, Baker JR Jr (2002) Design and function of a dendrimer-based therapeutic nanodevice targeted to tumor cells through the folate receptor. Pharm Res 19:1310-1316

34. Lee H, Baker JR Jr, Larson RG (2006) Molecular dynamics studies of the size, shape, and internal structure of $0 \%$ and $90 \%$ acetylated fifth-generation polyamidoamine dendrimers in water and methanol. J Phys Chem B 110:4014-4019

35. Gachet C (2006) Regulation of platelet functions by P2 receptors. Annu Rev Pharmacol Toxicol 46:277-300

36. Todde S, Moresco RM, Simonelli P, Baraldi PG, Cacciari B, Spalluto G, Varani K, Monopoli A, Matarrese M, Carpinelli A, Magni F, Kienle MG, Fazio F (2000) Design, radiosynthesis, and biodistribution of a new potent and selective ligand for in vivo imaging of the adenosine $\mathrm{A}_{2 \mathrm{~A}}$ receptor system using positron emission tomography. J Med Chem 43:4359-4362 